\title{
Alternative future scenarios for South Korea in 2030
}

Hyeonju Son ${ }^{\mathrm{i}}$

\section{Introduction}

Since the 1960s South Korea (hereafter Korea, except occasionally) has transitioned from an agricultural to an industrial society, resulting in far-reaching social changes in contemporary Korean life. Although the world now considers Korea an advanced, high-income country, the recent global financial crisis, the ongoing challenges of a nuclear North Korea, the awareness of climate change, and the rise of a multi-polar world, the country is facing a high degree of uncertainty for its future. Furthermore, because Korea's future development has been unilaterally driven based on the modernization theory, it is focusing on economic development to be on par with other advanced countries and follow the established Western model. This focus has played an important role in determining the path of Korea's future. However, the current development trajectory of a modernization has repeatedly caused some serious problems: (a) the highest suicide rate among the 30 OECD countries [1]; (b) high inequality in terms of the economy, education, and politics of its citizens [2,3]; and (c) the widening generation gap [4]. Korean life is gaining a reputation for gross over-consumption and over-development. In order to create a new Korean model for the future and address the problems Korea faces, viable alternative societal scenarios should be considered.

In this context, this paper will develop five alternative future scenarios for Korea in 2030 . It also addresses the implications pertaining to the main direction of change over Korea's longterm future. The paper is structured as follows: Section 2 discusses a brief history of Korea's futures studies. Section 3 defines the concepts of alternative futures and scenarios and outlines the Alternative Futures method. Section 4 describes Korea's background in terms of its historical 
legacies, currents trends, and future challenges. Section 5 presents five alternative future scenarios and how each impacts Korean society, economy, politics, class, and other pertinent issues. Final remarks and several implications are presented in the last section.

\section{Brief history of futures studies in Korea}

The field of futures studies in Korea has steadily developed over the past four decades. This development can be divided into three phases: Emergence of Korea's futures studies (19681979), securing national foresight and establishing the diversities of futures studies (1980-1996), and the era of globalization and alternative futures (1997-2010).

In response to the emerging field of futures studies, Korea established 'the Year 2000 Committee' in Seoul in 1968 [5], but when its members recognized that future studies would extend beyond that year, the Committee changed its name to the Korean Society for Future Studies (KSFS) in 1969. KSFS played a pivotal role in the early development of futures studies by introducing its basic concepts and methods and pursuing relationships with international futurist groups [5-7]. In 1971, a few years after its inception, KSFS undertook the project, 'Korea in the Year 2000', funded by grant from the Ministry of Science and Technology, in conjunction with the Korean Institute of Science and Technology [8]. It was the first future-oriented research at the national level to envision what Korea would look like in 30 years. Also, the Delphi studies and technological forecasting were actively conducted to demonstrate the methodological experiment of the futures methods [8-11].

The second developmental phase involved securing national foresight and the diversities of futures studies (1980-1996). In the 1980s, Korea was governed by an oppressive military dictatorship, and the state's repressive methods disallowed free speech and critical thinking. 
Therefore, state-owned think tanks dominated future-oriented activities, whereas public futures studies was at a standstill. For instance, the Korea Development Institute, one of the most influential Korean governmental think tanks, established a Long-Term National Strategy Program (1985) to build a national development model and Future Industry Task Force (1986) to address future industries in an advanced country $[12,13]$. Moreover, many ministerial think tanks contributed to future-oriented researches in the 1980s. But the late 1980s, Korea's authoritarian state changed to a more democratic-oriented state following the struggle for democratization. Futures studies took advantage of the rise in democratization and its subjects such as the civil society, human values, democracy, robotics, computers, and automation [12] illustrated its diversity, and went beyond the national development future. For example, the Science and Technology Policy Institute (STEPI) played an important role in securing the national foresight and sponsored the Delphi studies in 1993 and 1998 [14].

The third developmental phase centered on the era of globalization and alternative futures (1997-2010). In 1997, Korea faced what is known as the Asian Financial Crisis. Most Koreans were shocked by this economic downturn. As a result Korea has not only called for the development of economic globalization, but also for more future-oriented approaches to prevent further economic and social disasters. Moreover, Korea introduced ideas of alternative futures to overcome the national challenges of the twenty-first century. The public and private sectors began using various methods such as trend analysis, scenarios, visioning, and system dynamics. Accordingly, alternative futures have become a dominant part of futures studies: these include Korea's development model [15], a vision for science and technology [16, 17], a dream society [18], a national vision [19], a conserver society [20], and alternative scenarios [21-24]. In this period, qualitative trend analysis dominates corporate foresight [25, 26]. Many corporate think 
tanks such as Samsung Economic Institute and LG Economic Research Institute have produced trend-related working papers for market review [27, 28].

\section{Definitions and methods}

\subsection{Alternative futures}

Analysis of alternative futures is the main and most important discourse in the futures field. The long-standing popularity of alternative futures reflects the basic assumption that the future cannot be determined solely by natural and social forces and scientific laws. In other words, the belief that we live in a complex and uncertain world forms the concept of an alternative future. The concept of alternative futures is closely linked to the unpredictable future and the reversal of established trends. Alternative futures are explicitly opposed to making a single prediction. Extrapolated values such as linear or growth trends are viewed with skepticism. Furthermore, the concept of alternative futures allows us to make choices between two or more scenarios.

\subsection{Scenarios}

After Kahn's introduction of scenarios, we see that there are numerous definitions of the term 'scenario' $[29,30]$. In general, the definition of a scenario can be roughly divided into two strands: an inquiry-driven definition and a strategy-driven definition. One the one hand, the inquiry-driven definition is based on questions, queries, and imagination. The main purpose of this definition is to explore and promote radical imagination and raise curiosity in order to develop future-related questions. In this context, the scenarios provide answers to possible questions for future generations. This definition usually involves creating new images of the 
future and identifying which are preferred. On the other hand, strategy-driven definitions of scenarios could be called scenario planning or scenario building. Its main purpose is to enable decision makers to develop different possibilities for establishing the organization's strategic planning. Most business companies use this approach that usually involves problem solving and a project-based approach. Despite their conflicting ideas, inquiry-driven and strategy-driven scenarios are complementary: Inquiry can lead to even greater strategies since core assumptions can be challenged by allowing for novel strategies. In turn, strategies can provide feasible imaginative solutions to inquiry due to the specific goal orientation of the strategy.

This paper focuses more on the inquiry-driven definition of scenario. Rotmans et al.'s [31] notion of scenario reflects well the inquiry-driven definition of scenario: "archetypal descriptions of alternative images of the future, created from mental maps or models that reflect different perspectives on past, present and future development."

\subsection{Methods}

The Korea 2030 scenario employs Dator's Alternative Futures method that stresses images of the future because these exist everywhere humans live and dominate human culture [32]. He suggests four generic alternative futures: (a) continued growth, (b) collapse, (c) a disciplined society, and (d) a transformational society [33]. This scenario method focuses on developing the preferred future after experiencing examples of the four generic alternative futures. In order to create alternative future scenarios, this study presents four alternative scenario archetypes and one preferred future scenario. As shown in Table 1, four images of the future in Korea are possible. These scenarios first examine the question of what will happen in Korea if it shows continued economic growth, if Korea encounters extreme weather events, if 
cosmopolitan values permeate all strata of Korean society, and if Korea radically experiences high biotech development. After analyzing these four generic alternative scenarios and assessing their implications, a preferred future scenario is created. This study also employs Inayatullah's Causal Layered Analysis (CLA) [34] that examines the levels of litany, social causes, the discourse/worldview, and myth/metaphor, for each scenario summary.

Table 1. Development of Five Alternative Scenarios

\begin{tabular}{|c|c|c|c|}
\hline $\begin{array}{c}\text { Generic Images } \\
\begin{array}{c}\text { Continued } \\
\text { growth }\end{array}\end{array}$ & $\begin{array}{c}\text { Korean Future Images } \\
\text { Continued economic growth } \\
\text { society }\end{array}$ & The Republic of Samsung & $\begin{array}{c}\text { Main Driving } \\
\text { Forces }\end{array}$ \\
\hline Collapse & $\begin{array}{c}\text { Extreme climate society } \\
\text { Discipline }\end{array}$ & $\begin{array}{c}\text { The Great Han River Flood in a } \\
\text { Warmer Korea }\end{array}$ & Environment \\
\hline Transformation & High bio-tech society & $\begin{array}{c}\text { The Big Human Global Family } \\
\text { Phenomenon }\end{array}$ & Socio-cultural \\
\cline { 2 - 4 } & \multicolumn{1}{|c|}{$\begin{array}{l}\text { Envisioning } \\
\text { preferred } \\
\text { future }\end{array}$} & Technology \\
\hline Preferred future & Unification society & $\begin{array}{l}\text { Peaceful Unification as a Dream } \\
\text { Come True }\end{array}$ & Governance \\
\hline
\end{tabular}

\section{Historical legacies, trends, and future challenges in Korea}

\subsection{Historical legacies}

The past is an important element for understanding the future because the past affects the future, that is, the past is the memory of human experience. Without the past, we cannot figure out who we are, or where we want to go. Table 2 presents four historical legacies to understand Korea's past.

Table 2. Korea's Key Historical Legacies

\begin{tabular}{|l|l|}
\hline Historical Legacies & Contents \\
\hline Confucianism [35-37] & $\begin{array}{l}\text { Loyalty and filial piety; hierarchical interpersonal } \\
\text { relationship; the importance of education. }\end{array}$ \\
\hline Japanese Colonization [38, 39] & A pattern of conflictual engagement between the \\
\hline
\end{tabular}




\begin{tabular}{|l|l|}
\hline & $\begin{array}{l}\text { repressive state and the resistant civil society; high- } \\
\text { growth oriented development }\end{array}$ \\
\hline Anti-Communism $[40,41]$ & $\begin{array}{l}\text { Fear of Communism and the North Korea; ideological } \\
\text { legitimization of state }\end{array}$ \\
\hline Americanization [42- 45] & $\begin{array}{l}\text { Internalization of American values; a heavy } \\
\text { dependence on American academic community. }\end{array}$ \\
\hline
\end{tabular}

\subsection{Key trends}

Trends are influential forces that shape the future in all areas for the next 10-20 years. Because they can define the current and future development of society, future studies rely on trends. Table 3 presents the clustering of key trends to understand present-day Korea.

Table 3. Korea's Key Stable Trends

\begin{tabular}{|l|l|}
\hline Trends & Contents \\
\hline Population $[46,47]$ & $\begin{array}{l}\text { Declining population; aging population; rapid } \\
\text { urbanization. }\end{array}$ \\
\hline Energy $[48,49]$ & $\begin{array}{l}\text { Growing demand for more energy; decreasing } \\
\text { solid fuel and electricity; increasing renewable } \\
\text { energy and gas. }\end{array}$ \\
\hline Economy [50, 51] & Knowledge-based economy; globalization. \\
\hline Environment [52-54] & Global warming; extreme weather. \\
\hline Culture [55- 58] & $\begin{array}{l}\text { Postmodern culture: the convenience culture and } \\
\text { the culture of social networking }\end{array}$ \\
\hline Technology [59,60] & $\begin{array}{l}\text { The era of converging technologies; social } \\
\text { network technologies and applications. }\end{array}$ \\
\hline
\end{tabular}

\subsection{Key future challenges}

Korea is facing several challenges that signal risks and opportunities. These challenges attempt to draw the great transformation of the future not only by providing new interpretations of the past, but also by offering new visions of what the future might hold for Korea. Table 4 presents key future challenges.

Table 4. Key Challenges to Korea's Future

\begin{tabular}{|l|l|}
\hline Challenges & Contents \\
\hline Aging society [61-63] & $\begin{array}{l}\text { Threats of potential economic and enormous fiscal } \\
\text { pressures; a critical loss of knowledge and severe } \\
\text { shortage of skills; social instability by the huge influx } \\
\text { of international migration. }\end{array}$ \\
\hline
\end{tabular}




\begin{tabular}{|l|l|}
\hline Rise of the multi-polar world [64-66] & $\begin{array}{l}\text { Possibility of shifting alliances; involvement in the } \\
\text { great power struggle among great nations. }\end{array}$ \\
\hline North Korean challenges [67-69] & $\begin{array}{l}\text { Another Korean War; a possibility of Korean } \\
\text { unification; nuclear arms race in the Northeast Asia }\end{array}$ \\
\hline Export dependence [70,71] & $\begin{array}{l}\text { Export pessimism: significant instability from global } \\
\text { economic and financial turmoil. }\end{array}$ \\
\hline $\begin{array}{l}\text { Lack of natural and energy resources } \\
{[68,72,73]}\end{array}$ & $\begin{array}{l}\text { High-energy prices; new energy alliances; new } \\
\text { energy technologies. }\end{array}$ \\
\hline
\end{tabular}

\section{Five alternative future scenarios for $\mathbf{2 0 3 0}$}

\subsection{Continued growth scenario: The Republic of Samsung}

\subsection{1 background}

In this scenario, the dominant paradigms and trends that currently organize Korean society continue without significant change. The Samsung Group is a huge multinational conglomerate and has become the best-known global brand name. The title 'the Republic of Samsung' reflects a future in which business organizations dominate Korean society. In this future, the ethos of expansion, neoliberal ideals of competition, and market-led social policy have become widespread in Korea, and economic factors are the main driving forces.

\subsubsection{Society and economy}

Looking toward 2030, the Korean population has increased to 52.2 million from 48.0 million in 2010, with the percentage of the elderly increasing to 24.3 percent from 11.3 percent [46]. The society is experiencing an era of prosperity and optimism. Many Koreans agree that their life is much better now that manufacturing and export growth is thriving. The new convergence of technology with biotechnology and nanotechnology is expected to remain strong. Korea's GDP per capita ranks $15^{\text {th }}$ in the world and has risen nine places, from $24^{\text {th }}$ place in 2010 [74]. Koreans are enjoying more elegant cars, exotic foods, personal identity inspired clothes, 
and Internet-based entertainment. Space tourism industry is a new emerging market. Large conglomerate companies dominate the Korean economy. They are responsible for nearly 80 percent of the country's exports and account for more than half of all industrial production. Korea is vigorously carrying out conglomerate-favoring industrial and trade policies. Furthermore, the corporate culture disseminates into the society and is perceived as the standard for ethical attitudes and proper conduct.

Over the past two decades, Korea has become a center of a new knowledge economy. High-tech sectors and enterprise are the main drivers of its economic development. Korean biotechnology, genomics, and pharmaceutical companies hold a large percentage of global-level patents. Another area of rapid growth is the BCI (Brain Computer Interface) economy and it is central to economic innovation. The BCI technology represents a "man-computer symbiosis" for "an expected development in cooperative interaction between men and electronic computers" [75]. It is a potential ability of humans to control computers, machines, and devices by thoughts, emotions, and mental concentration [76]. BCI technology-related devices have dramatically changed Korean economics as they are the fastest-selling items in consumer products. Furthermore, many companies are responding to Korea's aging populations. Health care and senior care businesses are fast-growing enterprises, and robotics and tele-presence reality are involved in the senior care industry; for example, robotic pets and "prototype robotic telepresence nurses" [77] are indicators of how much technology is contributing to this growing industry.

\subsubsection{Politics and class}


The income of the wealthiest 1 percent of Koreans has nearly quadrupled over the past two decades, whereas the bottom 80 percent of the remaining Korean population shows only modest growth. The richest 1 percent holds more than half of the nation's financial wealth and defines their privileged way of life. Korean politics is dominated by the aforementioned 1 percent. As the plutocracy emerges, their rights and freedom are placed above those of the common people. They exert heavy influence on political parties and elections through lobbies, donations, charitable giving, and media. The wealthy donate large amounts of money to universities, foundations, and think tanks to promote their chosen causes. They have created a national database to connect their alliances and collect information through Big Data technologies. The dominance of a plutocratic-society is evidenced by several negative aspects: (a) damage to Korea's democracy because of the underdevelopment of pluralism; (b) the huge power of the wealthy increases the role of money in politics; and (c) economic polarization intensifies social conflicts and leads to the collapse of the middle class.

The dominance of globalization, the technology revolution, and financial deregulation lead to new masters and new employees as the new class structure forms itself. According to a survey to gauge Korea's national consciousness in 2030, over 90 percent of the survey respondents believe that "hyper-nomads" [78] are the most powerful group for change in Korea as the new ruling class. They comprise "a new innovative class" who strongly influence society and include holders of the capital of business, financial or business strategists, insurance and leisure company executives, software designers, creators, jurists, financiers, authors, designers, artists, creators of nomadic objects [78]. In contrast to the hyper-nomads, their employees are roughly divided into two categories: "virtual nomads" and "infra-nomads" [78]. On the one hand, virtual nomads respond to the demands for new technology and produce new social networks. 
They are middle class and include skilled workers, doctors, lawyers, developers, and engineers. They are characterized as having strong autonomy and flexible working hours. On the other hand, infra-nomads are members of the lower class, that is, unskilled workers with low income. As more technology and the cheap labor of foreign migrant workers are introduced, these workers become more and more disadvantaged in terms of unemployment and poverty.

\subsubsection{Issues}

Korea in 2030 faces two major issues: techno-consumerism and the age gap. Korea spreads more weird stories than other countries when the wave of BCI technology hits the world. Techno-consumerism replaces traditional consumerism. Koreans have experienced how far technology can be advanced; a happy life depends on how satisfied people are with technology. They measure human progress in terms of technology rather than spiritual advancement or individual freedom. According to the article entitled 'Korea's New Weird Society' in The New York Times dated August 2030:

Korea is number one in the world in terms of comprehensive BCI adoption. Mrs. Jungan, who is an international higher education specialist, wakes up at 5:30. She wants to listen to music, specifically Simon and Garfunkel's 'Bridge over Troubled Water'. A tiny machine that hangs on the wall in the master bedroom tracks her thoughts and activities. It is connected to "inconspicuous wireless sensors" [79] on her body for the monitor. The machine directs the music player to play Simon and Garfunkel's song. If she wants to make her own music, she can create melodies and rhythms by mental concentration. She benefits from this “digital nervous system” [79]. 
New conflicts begin to emerge between the younger generation and the older generation over economic policy preferences. Because of the huge increase in the economic gap between the two generations, the inter-generational conflict is more about economic policy preferences rather than ideology or values. On the one hand, the younger generations feel that the future of the economy is out of their hands due to the jobless growth rate, their early debt problems, and rising housing prices. Furthermore, the household income of the young generation is significantly less than that of the older generation. Required to pay high taxes to support pension benefits and health care costs for seniors, the younger generations agitates for reducing social welfare and pension system to reduce their financial burden. On the other hand, the older generation claims their right to be protected by the existing programs. Life expectancy numbers are increasing, and the growing number of seniors protest against cuts in the social welfare programs for seniors. The Korean Association of Retired Persons and the Korean Silver Party support the strengthening of the right of seniors.

\subsubsection{Summary}

As presented in Table 5 on the CLA of the Republic of Samsung, the main issue at the litany level is the continued growth of the conglomerate-dominated economy. Because the size

of the Korean economy is steadily growing, along with the conglomerate-favoring industrial and trade policies, conglomerates exert a powerful influence on nearly every aspect of Korean life, and market-and techno-optimism are appearing as subjects of discourses. Market-oriented reforms are seen as social and economic progress. Koreans are fortunate to have so many ways to access high-tech devices. The dominating metaphor and myth is that Korea is an affluent 
society and Koreans are living in a true advanced society. However, this scenario represents not only an era of great economic growth, but also an era of inequality. The era of inequality, including plutocracy, suggests that a true advanced society is an illusion.

Table 5. The Republic of Samsung: Causal layered analysis

\begin{tabular}{|l|l|l|l|}
\hline Litany & Social cause & Discourse/worldview & Myth/metaphor \\
\hline $\begin{array}{l}\text { The continued growth } \\
\text { of conglomerate- } \\
\text { dominated economy }\end{array}$ & $\begin{array}{l}\text { Conglomerate-favoring } \\
\text { industrial and trade policy } \\
\text { A robust corporate } \\
\text { governance }\end{array}$ & $\begin{array}{l}\text { Market and techno } \\
\text { optimism }\end{array}$ & $\begin{array}{l}\text { Korea is an affluent } \\
\text { society } \\
\text { A true advanced society }\end{array}$ \\
\hline
\end{tabular}

\subsection{Collapse scenario: The great Han River flood in a warmer Korea}

\subsubsection{Background}

Korea encounters catastrophic weather events, contributed by global warming. Korea is affected by ocean storms and ensuing heavy floods, and the death toll after the worst floods has risen to thousands. The great flood causes a nationwide blackout, resulting in the near collapse of the government's functions. The fundamentals of Korean society are destroyed as the Korean government cannot provide basic services for the recovery from the disaster. Accordingly, it can be called the collapse scenario rather than the crisis scenario. Environmental degradation is a main driving force for this scenario.

\subsubsection{Society and economy}

From 2010 onward Korea's prospects grow more and more dire. The discourse of risk and danger are occupying all Korean public perceptions and thoughts. By 2030 the total population has steadily decreased due to the fear of a high-risk society. The population reached its peak of 51.0 million in 2016, from 48.0 million in 2010; then it slightly decreased [46]. Global hazards are awakening a sense of crisis about safety in Korea in contrast to the previous aura of prosperity. For instance, in 2015, a Chinese space laboratory module exploded shortly 
after docking with a Chinese spacecraft. The explosion was caused by a powerful meteor storm. Chinese crews were unable to effectively operate the defense mechanism due to a terrible computer miscalculation. The next year, in 2016, a cholera epidemic hit the Texas Gulf Coast in the United States, following a tropical storm and ensuing floods. The epidemic killed several hundred people and affected millions nationwide. Much of the debates about the risk society caused by the rapid modernization and climate change are more closely linked to conspicuous consumption.

In the spring of 2027, the most disastrous flood in Korea history occurs along the Han River that dissects Seoul. It rained for about three weeks and flooded Seoul and other nearby cities. Mr. President declares the flooded areas as a special disaster zones to prevent looting and in order to respond as effectively as possible to the crisis. Dead bodies are everywhere. The flood affects about one-fourth of Korea, killing thousands of individuals, ruining crops, destroying tens of thousands of buildings, and causing hundreds of thousands of people to be evacuated from their homes. Koreans knew that the heavy rain would come, but they could not imagine the disastrous aftereffects.

As the results of the massive natural disaster, most Koreans take a skeptical view of the conventional economic growth model. They reject the consumption-oriented policy of promoting economic growth and trade at the expense of the environment. They oppose Korea's fast-paced society with its accelerating progress of technology and science because they believe that sustainable development is the most important source of a real alternative to avoid future nightmares. They are looking for radical change and a new economy. Korea's actions toward a low-consumption lifestyle, along with an economic contraction slogan, are fundamental. Achieving a degrowth society is the natural outcome of the destructive flood. 


\subsubsection{Politics and class}

Extreme weather events have become the heart of socio-political issues, dividing the nation into many incompatible factions. The progressive and conservative parties remain at an impasse on funding and climate-related legislations. The conservatives argue that government should start scaling back on the disaster relief fund to respond to extreme weather. They worry about higher taxes for the rich when dealing with the climate change agenda. The conservative party rejects the latest progressive party's proposals. It blocks cap-and trade legislation, including a carbon tax and new energy efficiency bills. The progressive party tries to introduce environmental tax reform, as climate change issue is a critical part of its platform. Many Koreans believe that the recent extreme weather events are evidence of global warming. On the one hand, some Korean conservative Christians see the extreme weather as a sign from God. They are obsessed with the apocalyptic idea. Religious leaders predict the Day of Judgment. Because Christians account for about one-third of Korea's population, they represent one of the most important voices in Korean politics. Theocracy is introduced into Korean politics. On the other hand, the progressive party and a large number of humanist groups criticize Christian theocracy and view the extreme weather as an outcome of modernity.

Koreans are exposed to severe conditions ranging from disasters to everyday risks. The poor have very limited resources with which to protect themselves from severe weather conditions, whereas the rich spend huge sums of money to protect themselves from deadly conditions. In 2025, a rare early November heavy snowstorm slammed Seoul. Ha-Il, a 31-yearold high school teacher, who resided in downtown Seoul, had to go to her best friend's house for two nights because she had no power in her house due to the storm. Power was out all over her 
part of town. But her friend had the biggest hydrogen fuel cell generator and was able to keep lights and home appliances running for several days. During the era of extreme weather events, generators become a necessary amenity. Koreans use them as a status symbol because lower income families cannot afford to buy this expensive method for survival. The elite, however, have other means to survive power outages. During the snowstorm, Mr. Kim, CEO of One Safe Security Company, fled to a disaster-resistant vacation house. Reinforced by an impact-resistant roof and window system, the disaster-resistant vacation house also has a safe room. Built to resist earthquakes, floods, snowstorms, and other natural disasters, the house was also equipped with high-tech communication devices. The weatherproofed vacation house allows his family to stay safe during natural disasters. Purchasing disaster-resistant vacation houses are en vogue and common for upper class and elite groups. When disasters strike security and welfare are markers of class identity. Disaster-resistant vacation houses represent class privileges and tastes.

\subsubsection{Issues}

Two main issues emerge in the collapse scenario: (a) no foreign aid to Korea, (b) and environmental refugees. Extreme weather events become a worldwide phenomenon as most countries are affected by severe weather. There is a high death toll and high economic losses. To make matters worse, severe weather situations have a negative impact on world transportation systems such as road, rail, aviation, and navigation. The Korean government appeals to the international community for humanitarian aid because it has lost its capacity to feed its citizens. There is no response from the international community. The United Nations aid programs have failed. Even the Development Assistance Committee of the OECD can no longer help Korea. 
In 2023, The International Organization for Migration (IOM) declared that the number of environmental refugees is in the millions. More people are emigrating to escape from the difficult environmental situation. The number of environmental refugees is increasing much more rapidly than before, and the International Environmental Refugee Project establishes the Floating Eco-Habitat Project, supported by the Global Climate Fund and environmental charities. The project has two branches: (a) the Floating Artificial City Project, and (b) Water Floating House Project [80, 81]. The city project built enormous floating artificial islands to provide homes for environmental refugees. It moves around the world as a self-sufficient shelter for about 50,000 people. Powered by renewable energies such as solar, wind energy, hydraulic and a tidal power station, and fitted with flexible pipes for sewage and electricity, the house project is made up of multiple floating building structures.

\subsubsection{Summary}

Table 6 presents the four levels of CLA for the Great Han River in a Warmer Korea scenario summary. At the litany level, extreme weather events have increased across the nation. Koreans demonstrate for stronger safety precautions. At the level of social causes, Koreans fail in their attempt to slow down extreme weather events due to conspicuous consumption and climate change. Therefore, the whole-home hydrogen fuel generator system and disaster-resistant vacation home become a symbol of social and economic status. In 2027, Korea experiences a massive flood that seriously destabilizes the people, economy, society, and culture. The Korean government collapses. The primary discourses argue for natural disaster prevention and degrowth. Disaster preparedness and relief are important values. As a result, Koreans seek to spread the following rhetoric as metaphors: a low-consumption life and an economic contraction 
slogan. The de-growth movement believes that the existing political institutions and economic systems are the main causes of the climate crisis.

Table 6. The great Han River in a warmer Korea: Causal layered analysis

\begin{tabular}{|l|l|l|l|}
\hline Litany & Social cause & Discourse/worldview & Myth/metaphor \\
\hline $\begin{array}{l}\text { The increase of } \\
\text { extreme } \\
\text { weather events }\end{array}$ & $\begin{array}{l}\text { Conspicuous } \\
\text { consumption and } \\
\text { climate change }\end{array}$ & $\begin{array}{l}\text { Natural catastrophe } \\
\text { De-growth }\end{array}$ & $\begin{array}{l}\text { A low-consumption lifestyle } \\
\text { An economic contraction slogan }\end{array}$ \\
\hline
\end{tabular}

\subsection{Disciplined society Scenario: The big human global family phenomenon}

\subsubsection{Background}

In this scenario, Korean society moves toward becoming a global family with cosmopolitan values. Global citizenship beyond the nation-state emerges. The belief in a universal human community without borders is embedded into everyday life in Korea. This scenario supports the concept of liberal cosmopolitanism rather than radical cosmopolitanism. Liberal cosmopolitanism emphasizes the role of a nation, whereas radical cosmopolitanism rejects the notion of special obligations to fellow nationals or citizens [82, 83]. Socio-cultural factors are the main driving force in the disciplined scenario.

\subsubsection{Society and economy}

The discourse on becoming a multicultural society could be seen as a major issue for Korea beginning in 2010 onward, galvanized by the issues of aging population, the low birth rate, and globalization. Along with the growing number of immigrant and international marriages, the number of people who became Korean citizens has risen rapidly; higher education institutions and global companies report an increase in the number of international students and foreign employees. Korea shows a relatively high growth of population, explained by increasing international migration. In 2030, the population is estimated at 55.0 million. Moreover, Korea is 
undergoing a remarkable transformation toward becoming a cosmopolitan society. The global citizen movement is vigorously activated by a variety of groups to represent a new way of life for the cosmopolitan society. The Solidarity for Global Civil Society (SCGS) is one of the forerunners for the global citizen movement in Korea. The purpose of this movement is to rethink global citizenship and global democracy. Moreover, its aim is to protest anti-neoliberal globalization and anti-neo nationalism and to stand for global justice. SCGS has been organizing for months on social media and community organizations, calling for coping with narrow territorial-based affiliations and struggling against the exploitation of citizens around the world.

In addition, regional economic, social, and political integration is accelerated by the spread of cosmopolitan values, unity in diversity, and the development of a pan-Asian identity. The discourse on a pan-Asian union is strongly advocated by several Asian countries for dealing with global justice, economic cooperation, regional peace, energy security, the spread of infectious disease, and frequent natural disasters. Among many Asian leaders and policy makers, there is fear and uncertainty surrounding the region's future. Korea's President initiates a series of meetings with other Asian countries, resulting in an agreement for the creation of a pan-Asian union with two critical visions: (a) the establishment of a unified market by 2025, and (b) the codification of Asian political cooperation.

The principles of economic cosmopolitanism have been eagerly applied to all economic activities affecting the people's economy. This new economy has come up with new paths out of overproduction, oversupply, and overinvestment. Social solidarity is determined to be more important than economic profits, evidenced by massive financial investments being so significantly constrained that the real economy dominates rather than the financial economy. In fact, many corporations attempt to serve their members and their communities instead of gaining 
financial profits. Business ethics and corporate social responsibility become common norms in the enterprise world. Most CEOs are concerned about how their companies affect the community, their employees, and environment. The integral part of a people's economy is the empowerment of the community economy to promote local development. Small and medium enterprises are becoming the main driving forces for Korea's development while conglomerates are no longer dominant. Business conditions of small and medium enterprises are dramatically improved.

\subsubsection{Politics and class}

In the cosmopolitan era, the landscape of Korean politics has transitioned from a statecentered approach to a multilevel governance approach. The Korean government does not have many power resources to impose its agenda on individuals and groups. Influenced by the "global public policy networks" [84] and other non-state actors, Korean politics require cooperation with other international political areas. The UN, the World Bank, and international non-governmental organizations have expanded their roles. The growth of multilevel governance challenges the dominant framework of Korean politics. The Left and the Right are continuously confronting with each other to secure hegemonic positions. On the one hand, because they are based in radical cosmopolitanism, the leftists oppose the role of the nation and hierarchical organizations. One of the prominent left-wing groups is the Global Stateless Society Center and its main ideology of anarchism advocating a stateless society without borders. On the other hand, the Right supports the existing political order of cosmopolitan democracy without any alternative framework. They see the limited state's authority to deepen democracy and to ensure equality Migration and cosmopolitan cultural practices are key factors for survival in a cosmopolitan society. There are two levels of power in the cosmopolitan Korean society: (a) 
transnational elites, and (b) provincialized masses. Transnational elites have been associated with "large clusters of high-waged professional and managerial expatriate workers" [85]. They are highly educated, highly paid, and highly mobile. They move easily from one country to another country and are not a homogenous group. Thus, they are interested in cultural power rather than political power. They are politically uncommitted elites. In contrast, provincialized masses encompass local professionals, local workers, low-income migrant workers, and refugees. They provide services to global elites, travelers, and seniors and exhibit a lack of cosmopolitan expertise and culture. For instance, the high mobility of the global elites harms local professionals. Although the local professionals should contest global elites who enter the local market, they eventually suffer the decline in their earnings and take a relatively minor position.

\subsubsection{Issues}

In this scenario, two key issues have arisen: (a) anti-migrant sentiment, and (b) loss of national sovereignty. Foreign immigrants' success stories have emerged with the rapid growth of the immigrant population. Amid the growth of this population and their influences, the neonationalism trend has emerged with an anti-immigrant stance. The massive flood of immigrants annoys the neo-nationalists, and they agitate to pass anti-immigration laws. They openly use anti-immigrant rhetoric: 'Korea's immigration disaster' and 'serious challenges of traditional values on a single bloodline.' For instance, in 2020, a bomb blast kills at least 100 migrant workers in the "Borderless Village" in Ansan City, in the Kyunggi Province, where hundreds of thousands have gathered for the annual migrant worker cultural festival. The terrorist attack is allegedly conducted by the Korean Nationalist Union, an extremist organization designed to stimulate anti-immigration movements. 
In 2028, a UN World Court is held to try a US president and several senior US officials on the charge of mismanagement of nuclear power, that is to be held accountable for a radiation leak at a dangerous level. This nuclear disaster results in scores of radiation deaths of foreigners. The failure of the US's response to the nuclear accident had led to the tragedy. The family of the victims accuse the US president and other US officials of second degree murder. The UN World Court also investigates the economic crimes made by the Chinese president and bankers that has generated worldwide economic ramifications. The Chinese bankers face allegations of collective embezzlement. The indictment of these global leaders by the UN World Court shows that the cosmopolitan legal order is functioning fairly. Cosmopolitan federalism dominates world politics as the primary governance mechanism. In this cosmopolitan political order, the Korean government renounces and relinquishes some of its sovereignty and collaborates with other international institutions.

\subsubsection{Summary}

Table 7 presents the main features of the CLA on the Big Global Family scenario. At the litany level, Korea shows a trend of a growing number of immigrants and international marriages, thus moving the country toward a multicultural society. The social causes of the multicultural society are its aging population, a low birth rate, and globalization. Cosmopolitanism dominates Korean political and social life as an important value. Two key discourses are global citizenship and multilevel governance that have permeated the cosmopolitan society as popular beliefs. Thus, the Korean government closely collaborates with other international institutions. The country has transformed itself into a people's economy. There are two metaphors: the negative effects of 
strong nationalism and practice of global justice. In this scenario, cosmopolitanism is seen as an equivalent to global justice and social advancement.

Table 7. The big global family: Causal layered analysis

\begin{tabular}{|c|c|c|c|}
\hline Litany & Social causes & Discourse/worldview & Myth/metaphor \\
\hline $\begin{array}{l}\text { The growing number of } \\
\text { immigrant and } \\
\text { international marriages } \\
\text { Rise of multicultural } \\
\text { society }\end{array}$ & $\begin{array}{l}\text { The aging } \\
\text { population } \\
\text { The low birth rate } \\
\text { Globalization }\end{array}$ & $\begin{array}{l}\text { Global citizenship } \\
\text { Multilevel governance }\end{array}$ & $\begin{array}{l}\text { The negative effects of } \\
\text { strong nationalism } \\
\text { Practice of global justice }\end{array}$ \\
\hline
\end{tabular}

\subsection{Transformational society scenario: The Age of Biotechnology}

\subsubsection{Background}

Korea has witnessed a historically unprecedented transformation brought on by developments in biotechnology that has fundamentally changed the Koreans' quality of life, healthcare practices, and business. The advancement of biotechnology helps them live longer, cure their diseases, and promote healthier living. This scenario addresses how the biotechnologies affect Korean lives and what opportunities and challenges have emerged. Technology factors remain the main driving force of this transformational society scenario.

\subsubsection{Society and economy}

In this scenario, the total population remains stable, but Korea becomes a super-aged society due to high-quality healthcare services and the advance of biotechnology. The impressive progress of genetic technology opens up the possibility of decoding the entire human genome sequence at a low, affordable cost. By and large, geneticists have unraveled the genetic roots of diseases like cancer, diabetes, and heart diseases. Koreans easily undergo genetic testing to analyze their own DNA sequence to discover their gene-related diseases. Genetic explanations appear everywhere: "it's all in the Genes," "the blood will tell," and "the master key to history" 
$[86,87]$. This language reflects a growing faith in genetic determinism. In the Korean culture obsessed with success and appearance, the eugenics movement is nationally gaining strength to improve human heredity. Younger generations are anxious to undergo genetic testing programs before marriage. They are predisposed to seek the advice of a geneticist to determine if their marriages should take place or not. Young adults and their parents prefer to use genetic testing to avoid having newborns with genetic diseases and consider genetic traits as an 'offspring's future diary.' In fact, some couples cancel their marriage plans due to their potentially dangerous genetic defects. The Korean government enacted the Anti-Discrimination Laws for Genetics to protect people against genetic discrimination in employment.

The Korean economy is undergoing fundamental structural changes, from IT sectors to bio-technology sectors. More pharmaceuticals and bio-product companies are seen in Korea's top five companies list. Automobile, steel, shipbuilding, chemical and semiconductor companies are falling far behind pharmaceuticals, medical devices, food and beverages, and life science companies. Many traditional chemical companies are restructuring themselves as life science companies. New agro-bio-technology companies dominate the agrochemicals and seed industries. Bio-medical alliances among pharmaceutical companies, biotech-related universities, and governmental agencies are emerging as the leading power groups in decision-making processes. More financial capital has been invested in medical devices and equipment companies than in any other companies. The news media has reported a significant boost in medical tourism: "Korea is the second largest medical tourist market in Asia."

\subsubsection{Politics and class}


New breakthroughs in biotechnology have relocated the source of power in terms of the society's social, political, and symbolic aspects. These innovations bring genetocracy, "organizing itself in informal biological cast systems" [88] to Korean politics. For the social order, all Koreans are categorized by "the qualities of their personal genome" [89]. The Korean Conservative Union, one of the nation's most powerful political groups on the Right, launches the 'Conservative Gene Project' which supports fertility experiments for human germline genetic modification, resulting in a more conservative inheritance. A growing body of work supports the belief that people's genes influence their political ideology. The project can be an important step in enabling conservatives to increase backers who will support conservative causes. In contrast, progressives have carried out a 'Liberal Gene Campaign,' which makes efforts to discover new genes leading people to have more liberal political attitudes. As a result, there are biotechnological conflicts among conservatives, progressives, and other stakeholders. Biotechconservatives are aligned with scientific and technological advances in the matters of social and economic development. They strongly support human cloning, stem cell research, and human genetic modification. However, biotech progressives focus on equality and the protection of human dignity. They criticize biotech-conservatives as having growth-oriented and utilitarian perspectives.

Reuters Korea provides two news-breaking stories in the summer of 2030. Recently, seven students in Korea committed group suicide due to genetic discrimination and prejudice. With the advancement of genetic manipulation technology, Korean society is divided into "the GenRich" and "Naturals." The GenRich class is "genetically enhanced" and considered "a modern day hereditary class of genetic aristocrats" [90]. The Natural class "cannot even breed successfully with their gene-enhanced betters" [91]. They are regarded as second-class citizens 
and "a genetically unemployable class [92]. The GeneRich class includes "GenRich

Businessman," "GenRich musicians," "GenRich artists," "GenRich intellectual generalists," and "GenRich athletes" [90]. The gap between the two classes is widening across the nation.

\subsubsection{Issues}

The development of biotechnology has led to the burgeoning ideology of transhumanism. The main discourse on transhumanism centers on how human enhancement by technology is beneficial to the society. Koreans expand their mental dependence on machines to their bodies. Many Koreans are obsessed with the promise of becoming superhuman. They have dreamed of having bodies and minds that transcend their biological limitations. For instance, Koreans have put electronic equipment into their bodies to control robotic arms and communicate with other people through the Internet. Koreans can experience the rapid and dramatic changes in the nature of their lives and minds. They can expect to achieve an indefinite life span in the near future.

In 2030, the life expectancy in Korea reaches a high of nearly 100.0 years, up from 80.0 in 2011. It opens up the age of centenarians (100+ years old). In the age of centenarians, the middle-aged population undergoes a transition that results in changes in several aspects of life. In the 1990s, the Korean middle-aged population, who were between 40-65 years old, was widely considered to be experiencing a midlife crisis. Today, middle age, which is considered as occurring between the ages of 60 and 80 , is seen as the prime time of life. The idea of midlife marks the turning point for a more mature stage of life. Middle-aged people show different lifestyles between the 1990s and the 2020s (see Table 8).

Table 8. Difference between the 1990s and the 2020s from the Middle Age [93, 94]

\begin{tabular}{|l|l|l|}
\hline & \multicolumn{1}{|c|}{ The 1990s } & \multicolumn{1}{c|}{ The 2020s } \\
\hline Discourse & Midlife crisis & Midlife transition \\
\hline Concepts & Declining years & Mature years \\
\hline
\end{tabular}




\begin{tabular}{|c|c|c|}
\hline Family setting & $\begin{array}{l}\text { Empty nest with boredom and } \\
\text { loneliness }\end{array}$ & $\begin{array}{l}\text { Happy nest with rich social } \\
\text { life and job satisfaction }\end{array}$ \\
\hline Physical condition & Physical decline & Physical strength \\
\hline Financial security & $\begin{array}{l}\text { Financial burdens with children } \\
\text { education costs. }\end{array}$ & $\begin{array}{l}\text { Financial burdens with } \\
\text { healthcare costs }\end{array}$ \\
\hline Character & $\begin{array}{l}\text { Middle-aged man with feminine } \\
\text { characteristics and middle-aged } \\
\text { women with assertive characteristics }\end{array}$ & $\begin{array}{l}\text { Middle-aged man and middle- } \\
\text { aged women with neutral } \\
\text { characteristics }\end{array}$ \\
\hline Behaviors & $\begin{array}{l}\text { Piecemeal change and an obsession } \\
\text { with mortality }\end{array}$ & $\begin{array}{l}\text { Radical change and impulsive } \\
\text { behavior about money and } \\
\text { career }\end{array}$ \\
\hline
\end{tabular}

\subsubsection{Summary}

The CLA of the Age of Biotechnology scenario is reconstructed in Table 9. At the litany level, Korea's biotechnology industry experiences dramatic growth. At the social causes level, Korea significantly invests huge financial resources into biotechnology and becomes a world leader. Furthermore, government policies are facilitating biotechnology as a key industry. The impressive progress of genetic technology opens up the gene age and genetic determinism as important social discourses. Koreans are living in an age where an individual's destiny is determined by his or her genetic makeup. The gene age and genetic determinism give way to genetocracy. Korean society is divided into the GenRich class and the Natural class. In addition, Korean society is based largely on the metaphor of the goals of super humans and a new frontier of biotechnology. Koreans promote the use of technology to enhance human capacities, believing that by technological intervention humans should contribute something special toward making progress in the society.

Table 9. The Age of Biotechnology: Causal layered analysis

\begin{tabular}{|c|c|c|c|}
\hline Litany & Social causes & Discourse/worldview & Myth/metaphor \\
\hline $\begin{array}{l}\text { Biotechnology } \\
\text { industry } \\
\text { experiences } \\
\text { dramatic growth }\end{array}$ & $\begin{array}{l}\text { impressive progress of } \\
\text { genetic technology } \\
\text { Investing financial resources } \\
\text { and concerted government } \\
\text { support to biotechnology }\end{array}$ & $\begin{array}{l}\text { The gene age } \\
\text { Genetic determinism }\end{array}$ & $\begin{array}{l}\text { The goals of super } \\
\text { humans } \\
\text { A new frontier of } \\
\text { biotechnology }\end{array}$ \\
\hline
\end{tabular}




\subsection{Preferred future scenario: Peaceful unification as a dream come true scenario}

\subsubsection{Background}

Beginning when Korea was divided in 1945 after the end of World War II, the most desired dream in Korea is peaceful unification. The unification scenario denotes a situation in which South and North Koreans support peaceful unification with gradual economic integration, and the two Koreas make efforts to institutionalize peaceful coexistence. After the unification, a unified Korea employs three fundamental normative principles: (a) an economic democracy, (b) an inclusive society, and (c) sustainable development, as important means to achieve a preferred future. Governance is the main driving force for this scenario.

\subsubsection{Society and economy}

The South Korea seeks to revive the Sunshine Policy for developing unification and decreasing the political tensions with the North. North Korea has implemented a Chinese style economic reform for a successful power shift since Kim Jong-un succeeded Kim Jong-il. There are highly visible power struggles between the various factions in the North Korean ruling class. The intense power struggle fatally undermines the internal cohesion and stability of the North Korea. To make the matter worse, North Korea experiences the massive volcanic eruption of Mt. Baekdu [95]. Despite the North Korean government's efforts in the recovery from the disaster, North Korea is confronted with an instable political climate, malfunctioning government system, international pressures, and anti-regime activities. The government needs innovative measures to deal with the current chaotic turmoil, that is, to find new ways of thinking that totally differ from the conventional wisdom. 
Unification is seen as the solution to end the turmoil. South Korea and North Korea establish the Korean Unity Joint Commission to prepare for all aspects of the unification. It sets up the three phases for the unification process: (a) Unification 1.0: Exchange, cooperation and rapprochement, (b) Unification 2.0: One country, three systems, and (c) Unification 3.0: New united Korea. In order to achieve the transition from a divided Korea to unification, four national unification projects are carried out:

1) Nationwide Unification Scenario Project: to develop the future of Korean unification and share the common vision.

2) East Asian Power Cooperation Project: to establish electric power interconnections to meet the fast-growing electricity demand and to support North Korea's severe electricity shortage [96].

3) The North Korea Reconstruction Program: to aid North Korea in rebuilding the North Korean's economy.

4) Reconstruction of National Identity: to help North and South Koreans adjust themselves to different values and their new environment during the unification process.

The unified Korea has a population of about 70 million. South Koreans account for twothirds of the total population, and North Koreans one-third. The unification simultaneously brings peace and hope. However, it generates much initial cost, and the two Koreas share the financial burden. Unification provides former North Koreans with more freedom and better living standards, whereas the slow economic growth after the unification inflicts some stress on former South Koreans. However, the unified Korea is transitioning to a new economic structure based on economic democracy and sustainable development, and the former South Korea's 
capital and technology and former North Korea's talented human capital and rich natural resources generates economic synergy. Military forces are reduced to 0.8 million from 1.6 million, resulting from the disarmament process. At the expense of the denuclearization of the unified Korea, the US, China, Russia, and Japan endorse the unified Korea. However, the process of unifying Korea creates five key problems: (a) unemployment, (b) massive migration, (c) disbarment and denuclearization, (d) group polarization, and (e) new nationalism.

The Unified Korea has transitioned from a fossil fuel energy economy to a sustainable energy economy, and from a neoliberal-oriented economy to an economic democracy. In order to tackle the flaws of the existing economic institutions and structures and achieve the preferred future vision, the economic democracy rests on six principles [97]: (a) regulation of market mechanisms and corporate activities, (b) moral, political and practical support of social enterprise, (c) democratic money creation processes, (d) a right to reclaim or re-create the commons, (e) redistribution of income and capital assets, and (f) a diversity of production scales and modes, including small-scale, subsistence and self-employment.

\subsubsection{Politics and class}

The debates on the unified political system have reverberated across the Korean peninsula for months. North Korea's unification formula is a loose form of a federation. In contrast, South Korea's unification formula is a confederation. How can a federation and a confederation pull together? How can a market society and a planned economy work together?

The Korean peninsula is trying to find a way to successfully merge the two former Koreas through scenario workshops, public hearings, surveys and focus groups, etc. One possibility is to enact the "one country, three systems" policy as an interim stage before complete national 
unification to overcome the distinctively different political and ideological gaps. This means that South Korea will maintain its capitalist system, while North Korea will retain its system of socialism. The third system will be built in the Demilitarized Zone (DMZ), which is an uninhabited narrow zone spreading across the Korean peninsula and separating South and North Korea. The two Koreas designate this space as the DMZ PAR (Peace Administration Region) to test the possibility of coexistence between South and North to the new vision society before completing the unification. The DMZ PAR is supported by the Korean Unification Trust Fund to build a new society, and once the DMZ PAR is established, two Koreas find it easier to transfer to a new society, and ultimately form a unified Korea.

Although it may be the 'dream come true' scenario, creating the unified Korea causes serious conflicts between its first-class and second-class citizens. Northerners feel like secondclass citizens marginalized from the mainstream of the unified Korea. Their payrolls are lower and their unemployment rates are high compared with South Koreans. These factors lead to isolation and a less confident life. Furthermore, some Southerners discriminate against Northerners and support right-wing activities such as neo-anticommunism. There is a physical difference as well: South Koreans are taller than North Koreans, and there is also a linguistic difference. The South Korean language is considered the official language, while the North Korean language is called a dialect. The popular discourse of the unification is that "The two Koreas are unified but not united."

\subsubsection{Issues}

With the achievement of the unified Korea, the Korean peninsula remains a less dangerous place in the world than before, but the country remains unstable. The divided Korea, 
despite its hostile atmosphere, provided foreign policies with a simple, bipolarized worldview: capitalism and communism. There was clarity in making decisions in terms of international politics on the Korean peninsula. Following the dissolution of the ideological conflicts and the neutralization of the unified Korea, the Korean peninsula becomes more complicated. The U.S and Chinese troops have withdrawn. The Unified Korea has severed all security treaties with the U.S. and China., and the power politics between China, Japan, Russia, and the US intensifies as the US, Japan, Russia, and China try to build a new order in Northeast Asia. China surpasses the United States economically and strongly challenges the U.S-led regional security order in Northeast Asia. China and the U.S. struggle for a regional leadership position. A new security structure is emerging.

\subsubsection{Summary}

Table 10 illustrates Korea's preferred future in terms of CLA. South Korea pursues the Sunshine Policy. North Korea carries out a Chinese-style economic reform, but it shows an increase in international political and related problems (the litany). North Korea suddenly makes an attempt to achieve unification to overcome political turmoil caused by a massive volcanic eruption and intense power struggles (social causes). North and South Korea need a radical transformation of their existing conditions. The discourse on the peace of the Koran Peninsula and new ways of thinking has an important role resulting in a peaceful unification and an equitable and sustainable society vision. However, there are also many problems that occur during the unification process such as high unemployment, massive migration, group polarization, new nationalism, and tension between northerners and southerners. Koreans are sympathetic to the metaphor, "the two Koreas are unified but not united." 
Table 10. Peaceful unification as a dream come true: Causal layered analysis

\begin{tabular}{|c|c|c|c|}
\hline Litany & $\begin{array}{l}\text { Environment/Social } \\
\text { causes }\end{array}$ & Discourse/worldview & Myth/metaphor \\
\hline $\begin{array}{l}\text { The increase of } \\
\text { internal political and } \\
\text { related problems in }\end{array}$ & $\begin{array}{l}\text { Massive volcanic } \\
\text { eruption } \\
\text { Highly visible power }\end{array}$ & $\begin{array}{l}\text { New ways of thinking } \\
\text { Peace on the Korean } \\
\text { peninsula }\end{array}$ & $\begin{array}{l}\text { The two Koreas are unified } \\
\text { but not united }\end{array}$ \\
\hline
\end{tabular}

\section{Conclusion}

By adopting Dator's Alternative Futures method, this paper has presented five alternative future scenarios of Korea in the year 2030 to increase our understanding of Korea's long-term future. Table 11 presents a summary of the differences among the five alternative scenarios in terms of society, economy, politics, class, and other issues. The Republic of Samsung scenario is the official view of the Korean future. Its vision is to attain global neoliberal capitalism; however, the free market system is fragile. This scenario suggests that increasing the dominance of technoconsumerism and widening the age gap curtails economic growth and compromises human dignity in all forms. To avoid the problems, Korea needs to tackle inequality and corporate dominance.

Table 11. Five scenarios comparison: Main features

\begin{tabular}{|c|c|c|c|c|c|}
\hline Scenarios & Society & Economy & Politics & Class & Issues \\
\hline $\begin{array}{l}\text { The Republic of } \\
\text { Samsung }\end{array}$ & $\begin{array}{l}\text { Corporate } \\
\text { society }\end{array}$ & BCI economy & Plutocracy & $\begin{array}{c}\text { Hyper-nomads, virtual } \\
\text { nomads, } \\
\text { Infra-nomads }\end{array}$ & $\begin{array}{l}\text { techno- } \\
\text { consumerism, } \\
\text { the rise of an age } \\
\text { gap }\end{array}$ \\
\hline $\begin{array}{l}\text { The great Han } \\
\text { River in a warmer } \\
\text { South Korea }\end{array}$ & Risk society & $\begin{array}{l}\text { Degrowth } \\
\text { economy }\end{array}$ & $\begin{array}{l}\text { The battle over } \\
\text { global warming }\end{array}$ & $\begin{array}{c}\text { A whole home } \\
\text { hydrogen fuel generator } \\
\text { system, disaster- } \\
\text { resistant vacation } \\
\text { homes } \\
\end{array}$ & $\begin{array}{l}\text { No foreign aid, } \\
\text { environmental } \\
\text { refugees }\end{array}$ \\
\hline $\begin{array}{l}\text { The big global } \\
\text { family } \\
\text { phenomenon }\end{array}$ & $\begin{array}{l}\text { Cosmopolitan } \\
\text { society }\end{array}$ & $\begin{array}{l}\text { People's } \\
\text { economy }\end{array}$ & $\begin{array}{l}\text { Multilevel } \\
\text { governance }\end{array}$ & $\begin{array}{l}\text { Transnational elites and } \\
\text { provincialized masses }\end{array}$ & $\begin{array}{l}\text { Anti-migrant } \\
\text { sentiment, loss } \\
\text { of national } \\
\text { sovereignty }\end{array}$ \\
\hline $\begin{array}{c}\text { The Age of } \\
\text { Biotechnology }\end{array}$ & Genetic society & Bio-economy & Genetocracy & $\begin{array}{l}\text { The GenRich class and } \\
\text { the Natural class }\end{array}$ & $\begin{array}{l}\text { Changing human } \\
\text { nature }\end{array}$ \\
\hline $\begin{array}{c}\text { Peaceful } \\
\text { unification as a } \\
\text { dream come true }\end{array}$ & Unified society & $\begin{array}{l}\text { Sustainable } \\
\text { economy }\end{array}$ & $\begin{array}{l}\text { One country, three } \\
\text { system policy }\end{array}$ & $\begin{array}{l}\text { First class and second } \\
\text { class citizen }\end{array}$ & $\begin{array}{l}\text { New type of } \\
\text { order in East } \\
\text { Asia }\end{array}$ \\
\hline
\end{tabular}


In contrast, the Great Han River in a Warmer South Korea scenario and the Big Global Family Phenomenon scenario fundamentally challenge the official vision of the future. The Great Han River in a Warmer South Korea scenario is a collapse scenario based on the ecosocialism vision that rejects the basic structure of neoliberal capitalism and the ways the environment is being degraded. This scenario indicates that Korea should move in a different direction from pro-growth ideas. Korea would suffer from natural disasters if Korea's current policies are not modified to take environmental degradation into consideration. Thus, Korea needs to put in place appropriate measures to address environmental problems.

The cosmopolitan universalism vision of the Big Global Family Phenomenon scenario originates from human-oriented attitudes and social justice, and challenges Koreans' consumption-oriented attitude and nationalism. This suggests that Koreans should advance beyond a multicultural society and international cooperation toward a cosmopolitan world that puts more emphasis on human rights and the fundamental freedoms of individual or groups. Furthermore, political activity can facilitate more generic universal interests transcending limited national interests for protecting human rights. In this context, Koreans need to practice global responsibility. Moreover, non-state actors continue to play pivotal roles in constructing the cosmopolitan world and reforming national politics for multilevel governance. We need to consider how non-state actors legitimize their involvement in the formal system.

The Age of Biotechnology scenario is an attempt to realize the post-modern desire for progress through biotechnology. It is not distinctively different from the Republic of Samsung scenario vision. However, in this scenario Korea is becoming a genetic-driven society. The notion of the genetic society has generated the spread of the transhumainsm vision. This scenario suggests that the promise of biotechnology and the pervasive power of genetics are threatening 
the dignity of human beings. The emphasis on the gene may diminish social responsibility for social and economic inequalities. Moral concerns and ethical discourse are extremely important in determining the policies in the development of biotechnology compared to previous economic development planning such as automobiles, semiconductor, and information technology. Thus, the development of biotechnology should go beyond technical performance and assessment.

The vision of Peaceful Unification as a Dream Come True scenario is the unification of two Koreas and the formation of an equitable and sustainable society. This vision challenges the one-sided nature of the official vision that only focuses on South Korea's future and embraces a desirable national goal as an idealized future. The unified Korea has successfully transitioned into a united nation from two antagonistic states. However there are serious issues affecting the unification process such as tension between Northerners and Southerners and the new order of power in East Asia. In this scenario, a massive volcano eruption has played a significant role in the unification process as a catalyst for social change. This scenario examines how natural disaster moves the unification process forward. Although political and economic conditions are important determinants that trigger Korean unification, natural phenomena and environmental factors should also be considered as critical variables in an unexpected or abrupt unification. To prepare for the future unification, the Korean society needs to engage in detailed discussions and form measurements for an abrupt unification. This scenario invokes the importance of non-social and non-political factors to realize the future of the united Korea. 


\section{References}

[1] J. Cho, Suicide rate soars to put Korea at top of OECD list, Joongang Ilbo, 25 March 2010.

[2] H. Koo, The changing faces of inequality in South Korea in the age of globalization, Korean Studies 31(2007) 1-18.

[3] S.J. Lee, Democratization and polarization in Korean society, Asian Perspective 29(3) (2005) 99-125.

[4] H. Schattle, South Korea's generation gap, The New York Times, 21 December 2012.

[5] KSFS (Korean Society for Future Studies), Mirae-reul Mutneunda 1 [An Inquiry into the Future I], Seoul National University, Seoul, 1970.

[6] KSFS (Korean Society for Future Studies), Mirae-reul Mutneunda II [An Inquiry into the Future II], Seoul National University, Seoul, 1970.

[7] KSFS (Korean Society for Future Studies), Mirae-reul Mutneunda III [An Inquiry into the Future III], Seoul National University, Seoul, 1971.

[8] KIST (Korean Institute of Science and Technology), Korea in the Year 2000, The Ministry of Science and Technology, Seoul, 1971.

[9] J. M. Sohn. The introduction to methodology of future forecasting of urban area I (Dosiui miraeyecheuke gwanhan bangbeopron seosel I), Urban Affairs (Dosi Munje) (1970) 50-68. [10] J.M. Sohn. The introduction to methodology of future forecasting of urban area II (Dosiui miraeyecheuke gwanhan bangbeopron seosel II), Urban Affairs (Dosi Munje) (1970) 86-113.

[11] H.S. Kim, et al., Technological forecasting: the Korean food industry (Hanguksikpumgongeopui miraeyecheukjakeop), Korean Journal of Food Science and Technology (Hanguksikpumgwahakhoeji) 4(1) (1972) 53-54.

[12] K.H. Bae, Mirae Sahoehak [The Sociology of the Future], Namam Publishing House, Seoul, 1995.

[13] KDI (Korea Development Institute), Miraee-ui Dojeon: Saneopgujo Byeonhwa-wa Jeongchaek Daeeung [The Challenges of the Future: Industrial Structural Change and Policy Responses], KDI, Seoul, 1987.

[14] T. Shin, S.K. Hong, H. Grupp, Technology foresight activities in Korea and in countries closing the technology gap, Technology Forecasting and Social Change (60) (1999) 71-84.

[15] A.Toffler, H. Toffler, Beyond the Crisis: Korea in the 21st Century, Toffler Associates and Korean Information Society Development Institute, 2001.

[16] Y. Choi, Technology roadmaps in Korea, Presented at the Second International Conference on Technology - Tokyo, Japan, 27-28 February 2003.

[17] M. Rader, Review and analysis of national foresight: case study Korea, FISTERA-Thematic Network, 2001.

[18] J. Dator, Y. Seo, Korea as the wave of a future: the emerging dream society of icons and aesthetic experience, Journal of Futures Studies 9(3) (2004) 31-44.

[19] Presidential Commission on Policy Planning, Korea's Future: Vision and Strategy-Korea's Ambition to Become an Advanced Power by 2030, Seoul Selection, Seoul, 2008.

[20] J. Dator, S. Park, Through a Brushwood Door: Should Korea Become a Conserver Society?, A Report to Korean Telecom, 2009.

[21] P.F. Chamberlin, Korea 2010: The Challenges of the New Millennium, The CSIS Press, Washington, D.C., 2001.

[22] H. Choe, S. Eum, M. Jeon, Digitalsahoe-ui Miraeyecheuk Bangbeopron Yeongu [Study on Future Forecasting Method for the Digital Society], Korea Information Society Development Institute (KISDI) Paper 06-20, KISDI, Gwacheon, Korea, 2006. 
[23] M. Noland, Avoiding the Apocalypse: The Future of the Two Koreas, Institute for International Economics, Washington D.C., 2000.

[24] J. Pollack, C.M. Lee, Preparing for Korean Unification: Scenarios and Implications, RAND, Santa Monica, 2000.

[25] KISDI (Korea Information Society Development Institute, Ed.), 21segi Hanguk Megatrend I-V [Korea's Megatrend in the 21 Century I-V], Mineumsa, Seoul, 2005.

[26] NIA (National Information Society Agency), Hanguksahoe-ui 15dae Megatrends [15 Megatrends in Korean Society], NIA, Seoul, 2010.

[27] LG Economic Research Institute, 2010 Daehanminguk Trend [2010 Korea Trend], The Korea Economic Daily, Seoul, 2005.

[28] Samsung Economic Research Institute, Healthcaresaneop-ui Megatrend-wa Hanguk-ui Gihoe [Healthcare Industry Megatrends and Opportunities for Korea], CEO Information, Seoul, 19 January 2011.

[29] T.J. Chermack, Scenario Planning in Organizations, Berrett-Koehler, San Francisco, 2011. [30] P. van Notten, Writing on the Wall: Scenario Development in Times of Discontinuity. Dissertation.Com, Boca Raton, 2004.

[31] J. Rotmans et al., Visions for a sustainable Europe, Futures 32 (2000) 809-831.

[32] J. Dator, The futures of cultures or cultures of the future, in: A. Marsella, G. Tharp, T.J. Ciborowski (Eds.), Perspectives in Cross-Cultural Psychology, Academic Press, New York, 1979, 369-388.

[33] J. Dator, Alternative futures at the Manoa School, Journal of Futures Studies 14(2) (2009) 118.

[34] S. Inayatullah, causal layered analysis: poststructuralism as method, Futures 30(8) (1998) 815-829.

[35] W.M. Hurh, The Korean Americans, Greenwood, Westport, 1998.

[36] J.K. Oh, Korean Politics: the Quest for Democratization and Economic Development, Cornell University Press, Ithaca, 1999.

[37] C.M. Park, D.C. Shin, Do Asian values deter popular support for democracy in South Korea? Asian Survey 46(3) (2006) 341-361.

[38] S. Kim, The Politics of Democratization in Korea: the Role of Civil Society, The University of Pittsburgh Press, Pittsburgh, 2000.

[39] A. Kohli, Where do high growth political economies come from?: the Japanese lineage of Korea's “developmental state”, World Development 22(9) (1994) 1269-1293.

[40] J.J. Choi, Political cleavages in South Korea, in: H. Koo (Ed.), State and Society in Contemporary Korea, Cornell University Press, Ithaca, 1993, 13-50.

[41] G.W. Shin, One Alliance, Two Lenses: U.S.-Korea Relations in a New Era. Stanford University Press, Stanford, 2010.

[42] L.W. Beer, Constitutionalism and rights in Japan and Korea, in: L. Henkin, A. Rosenthas, (Eds.), Constitutionalism and Rights: The Influence of the United States Constitution Abroad, Columbia University Press, New York and Oxford, 1990, 225-259.

[43] H. Park, English as fashion: English mixing in women's fashion magazines, Presented on the 9th Conference of Pan-Pacific Association of Applied Linguistics, Namseoul University, Korea, 2004.

[44] M. Kim, Language, the university, and American Studies in Korea, American Quarterly 57(2) (2005) 439-462. 
[45] J.I. Kang, Academic dependency: Western-centrism in Korean political science, Korea Journal 46 (4) (2006) 115-135.

[46] Korean National Statistical Office homepage. Available from

<http://kostat.go.kr/portal/korea/index.action>

[47] M. Jacques, When China Rules the World: The Rise of the Middle Kingdom and the End of the Western World, Allen Lane, London, 2009.

[48] Korea Energy Economic Institute (KEEI), Yearbook of Energy Statistics, KEEI, Euiwang-si, Korea, 2005.

[49] Korea Energy Economic Institute (KEEI), Yearbook of Energy Statistics, KEEI, Euiwang-si, Korea, 2011.

[50] M. Oh, J. F. Larson, Digital Development in Korea: Building an Information Society, Routledge, New York, 2011.

[51] KOF, Index of Globalization 2011.

[52] Chosun Ilbo, More heavy snow forecast, 14 February 2011.

[53] Chosun Ilbo, 39 dead, 8 missing in torrential rains, 28 July 2011.

[54] J. Lee, Extreme weather economics, SERI Economic Focus, 278(February 2), Samsung Economic Research Institute, Seoul, 2010.

[55] S. Jung, Korean Masculinities and Transcultural Consumption: Yonsama, Rain, Oldboy, KPop Idols, Hong Kong University Press, Hong Kong, 2011.

[56] S.K. Kim, Changing lifestyles and consumption patterns of the South Korean middle class and new generations, in: B.H. Chua (Ed.), Consumption in Asia: Lifestyle and Identities, Routledge, London, 2000.

[57] K.H. Kim, H. Yun, Crying for me, crying for us: relational dialectics in a Korean social network site, Journal of Computer-Mediated Communication 13 (2008) 298-318.

[58] Lee's Korea blog. Available from <http://leeskoreablog.blogspot.com/2010/03/convenienceculture.html> (cited in 11.05.11),

[59] S.L. Silberglitt et al., The Global Technology Revolution 2020, In-Depth Analyses:

Bio/Nano/Materials/Information Trends, Drivers, Barriers, and Social Implications, RAND

Corporation, Santa Monica, 2006.

[60] Reuters, South Korea smart phone subscribers exceed 20 million, 30 October 2011.

[61] N.Howe, R. Jackson, K.Nakashima, The Aging of Korea: Demographics and Retirement Policy in the Land of the Morning Calm, Center for Strategic and International Studies, New York, 2007.

[62] J. Schiff, M. Syed. The graying of Korea: addressing the challenges of aging, Korea's Economy 24 (2008) 7-13.

[63] A. Okamura, K. Onuma, K. Takehana, direction of Japan's strategy for economic growth towards 2030, Nomura Research Institute Papers. No. 159, 1 November 2010.

[64] E.H. Fry, Lament for America: Decline of the Superpower, Plan for Renewal, University of Toronto Press, Toronto, 2010.

[65] R.N. Haass, The age of nonpolarity: what will follow U.S. dominance, Foreign Affairs 87(3) (2008) 44-56.

[66] J. Kim, Continuity and transformation in Northeast Asia and the end of American

exceptionalism: a long-rang outlook and US policy implications, The Korean Journal of Defense Analysis xill(1) (2001) 229-261.

[67] Korea Times, Rising trade dependency, 20 December 2010.

[68] R.A. Manning, The Asian Energy Factor, Palgrave, New York, 2000. 
[69] National Intelligence Council, Global Trends 2025: A World Transformed. U.S. National Intelligence Council, Washington D.C., 2008.

[70] G.R.Winham, An interpretative history of the Uruguay round negotiation, in: P.F.J. Macrory, A.E. Appleton, M.G. Plummer (Eds.), the World Trade Organization: Legal, Economic and Political Analysis, vol. I., Springer, New York, 2005, 3-26.

[71] H. Chang, C.G. Yoo, The triumph of the rentiers?, Challenge 43(1) (2000) 105-124.

[72] U.S. Energy Information Administration, Annual Energy Outlook 2010 with Projections to 2035, DOE/EIA, Washington D.C., 2010.

[73] C. Daniel, Kissinger warns of energy conflict, The Financial Times, 2 June 2005.

[74] M. Matsutani, S. Korea poised to overtake Japan in GDP per capita by 2030: report, Japan Times, 19 April 2012.

[75] J.C.R. Licklider, Man-computer symbiosis, IRE Transactions on Human Factors in Electronics, HFE-1(March) (1960) 4-11.

[76] Y.T. Wang, Y. Wang, T.P. Jung, A cell-phone based brain-computer interface for communication in daily life, in: F.L. Wang et al. (Eds.), Artificial Intelligence and Computational Intelligence, International Conference, AICI 2010, Sanya, China, October 2010, Proceedings, Part II, Springer, New York, 233-240.

[77] T. Jones, Future Agenda: The World in 2020, Infinite Ideas, Oxford, 2010.

[78] J. Attali, A Brief History of the Future, Arcade Publishing, New York, 2006.

[79] L. Mickelberg, Pharma's digital future, Marketing Health, 27 January 2012. Available from $<$ http://www.mediapost.com/publications/article/166545/pharmas-digitalfuture.html?print\#axzz2Le4HIuTU> (cited 02.25.12)

[80] D. Flahiff, The waterpod: a floating eco-habitat, Inhabitat Website, 29 January 2009.

Available from <http://inhabitat.com/waterpod-floating-eco-home/> (cited in 01.13.12).

[81] Steph, 12 fantastic floating cities and artificial islands, Web Ecoist. Available from < http://webecoist.momtastic.com/2009/04/27/12-fantastic-floating-cities-and-artificial-islands/> (cited in 04.01.12)

[82] K.A. Appiah, Cosmopolitanism: Ethics in a World of Strangers, Penguin Books, London, 2006.

[83] M. Nussbaum, Patriotism and cosmopolitanism, in: J. Cohen (Ed.), For Love of Country: Debating the Limits of Patriotism, University of Chicago Press, Chicago, 1996, 2-17.

[84] G. Sørensen, The Transformation of the State: Beyond the Myth of Retreat, Palgrave Macmillan, New York, 2004.

[85] B.S.A.Yeoh, T. C. Chang, Globalising Singapore: debating transnational flows in the city, Urban Studies 38(7) (2001) 1025-1044.

[86] D. Nelkin, Molecular metaphors: the gene in popular discourse, Nature Reviews Genetics 2(7) (2001) 555-559.

[87] D. Nelkin, M.S. Lindee, Elvis's DNA: the gene as a cultural icon, The Humanist 55(May/June) (1995) 10-19.

[88] J. Somsen, Regulating Modern Biotechnology in a Global Risk Society, Vossiuspers UvA, Amsterdam, 2004.

[89] E.L. Graham, Representations of the Post/Human: Monsters, Aliens and Others in Popular Culture, Manchester University Press, Manchester, 2002.

[90] L.M. Silver, Remaking Eden: How Genetic Engineering and Cloning Will Transform the American Family, Perennial, New York, 2002. 
[91] L.M. Silver, It's not the meek who will inherit, Times Higher Education, 16 January 1998. Available from <http://www.timeshighereducation.co.uk/story.asp?storycode $=105415>$ (cited in 02.26.12).

[92] J. Rifkin, The Biotech Century: Harnessing the Gene and Remaking the World, Penguin Putman, New York, 1998.

[93] H. Jake, H. Giles, creating intergenerational distance: language, communication and middleage, Language Sciences 15(1) (1993) 15-38.

[94] H. Kiebler-Brogan, Are you having a midlife?, Available from

<http://www.iecounseling.com/uploads/Tools_Article_F08.pdf> (cited 02. 25.12).

[95] S. Park, Major eruption of Mt. Baekdu 'possible', The Korea Times, 18 June 2010.

[96] W.C. Yun, Z.X. Zhang, Electric power grid interconnection in Northeast Asia, East-West Center Working Paper, Environmental Change, Vulnerability, and Governance Series, no 63, March 2005.

[97] N. Johanisova, S.Wolf, Economic democracy: a path for the future?, Futures 44 (2012) 562570.

'Son, Hyeonju. 2013. "Alternative future scenarios for South Korea in 2030." Futures, 52: 27-41. 